та ін.]; за ред. В. О. Лозового. - К. : Юрінком Інтер, 2003. - 208 с. 2. Комарова А. И. Эстетическая культура личности / Алина Ивановна Комарова. - К. : Вища шк., 1988. 152 с. 3. Корниенко В. С. О законах красоты / Василий Степанович Корниенко. - Х. : Изд-во Харьковского ун-та, 1970. - 224 с. 4. Кунчева Л. И. Эстетические взгляды общества и художественная культура / Людмила Ивановна Кунчева. - М. : Наука, 1979. - 248 с. 5. Липский В. Н. Эстетическая культура и личность/ Владимир Николаевич Липский. - М. : Знание, 1987. - 128 с. 6. Лісова С. В. Естетична культура особистості як складова підготовки майбутнього фахівця в системі професійної освіти / С. В. Лісова // Вісник Житомирського державного університету ім. І. Франка. - 2010. - Вип. 50. - С. 60-63. 7. Прусак В. Ф. Організаційно-педагогічні засади підготовки майбутніх дизайнерів у вищих навчальних закладах України: дис. ... канд. пед. наук: 13.00.04 / Прусак Володимир Федорович. - Івано-Франківськ, 2006. 211 с. 8. Эстетическая культура советского человека/ под ред. М. С. Кагана. - Л. : Изд-во Ленинградского ун-та, 1976. - 168 с.

\title{
ТЕОРЕТИЧНІ ПИТАННЯ ФОРМУВАННЯ ВМІНЬ МОДЕЛЮВАННЯ У СТУДЕНТІВ ВИЩИХ ЕКОНОМІЧНИХ НАВЧАЛЬНИХ ЗАКЛАДІВ
}

Тюріна Д. М., Макарова Л. Г. Теоретичні питання формування вмінь моделювання у студентів вищих економічних навчальних закладів.

У статті розкрито науково-методичні засади процесу формуваннявмінь моделювання у студентів вищих економічних навчальних закладів: розкрито сутність поняття «уміння моделювання економічних об'єктів»; здійснено класифікацію вмінь моделювання економічних об'єктів відповідно до складників процесу моделювання; уточнено критерії, показники рівнів сформованості вмінь моделювання економічних об'єктів у студентів.

Ключові слова: моделювання, уміння, студент, вищий економічний навчальний заклад.

Тюрина Д. Н., Макарова Л. Г. Теоретические вопросы формирования умений моделирования у студентов высших экономических учебных заведений.

В статье раскрываются научно-методические основы процесса формирования умений моделирования у студентов высших экономических учебных заведений: раскрыта суть понятия «умения моделирования экономических объектов»; осуществлена классификация умений моделирования экономических объектов согласно составляющим процесса моделирования; уточнены критерии, показатели уровней сформированности умений моделирования экономических объектов у студентов.

Ключевые слова: моделирование, умение, студент, высшее экономическое учебное заведение.

Tyurina D. M., Makarova L. G. Theoretical Issues formation modeling skills in students of higher economic education.

The article deals with scientific and methodological basis of skills formation process modeling in students of higher economic education: the essence of concepts: «the ability of modeling of economic objects», the classification skills of modeling economic facilities in compliance with the modeling process, specified criteria, performance levels formation of economic objects modeling skills in students.

Key words: modeling, skill, student, institution of higher economical education. 
Економічна освіта у вищих навчальних закладах III-IV рівнів акредитації має на меті підготовку фахівців-економістів із сучасним світоглядом, професійними знаннями інноваційного характеру, вмінням моделювати економічні об'єкти під час розв'язання соціально-економічних проблем.

Сучасна економічна діяльність характеризується складністю та комплексністю об'єктів, невизначеністю, багатофакторністю економічних процесів, вирішення яких потребує застосування перспективного, порівняльного аналізу для дослідження кількох варіантів можливих управлінських рішень, оцінювання значного обсягу інформації, прогнозування соціально-економічного розвитку, моделювання економічної ситуації. Це потребує змін у системі економічної освіти, зокрема вдосконалення підготовки майбутніх економістів.

Водночас результати пілотажного дослідження свідчать, що 52,2\% від 385 майбутніх спеціалістів недостатньо володіють уміннями моделювання економічних об'єктів, а саме - самостійно визначати мету, розробляти моделі, аналізувати отримані результати; тільки $36,5 \%$ iз 52 опитаних викладачів усвідомлюють необхідність формування зазначених вище вмінь у студентів, але часто не співвідносять зміст навчального матеріалу з доцільністю здійснення цієї роботи.

Аналіз результатів теоретичних напрацювань науковців щодо практичного досвіду підготовки фахівців економічного профілю у вищих навчальних закладах до майбутньої професійної діяльності дозволив виявити низку суперечностей між: необхідністю виявлення сутності, критеріїв, показників сукупності вмінь моделювання майбутніх фахівців економічного профілю та недостатньою розробленістю їх у науці та практиці. Усунення зазначених суперечностей, практичне значення проблеми й недостатня розробленість ії теоретичних аспектів надають змогу стверджувати, що розв'язання проблеми формування вмінь моделювання у студентів вищих економічних навчальних закладів $\epsilon$ актуальною вимогою сьогодення.

Mema cmammi - обгрунтувати теоретичні засади формування вмінь моделювання у студентів вищих економічних навчальних закладів.

У процесіаналізу науково-педагогічних джерел (С. Архангельський, А. Вербицький, Б. Гнеденко, О. Горстко, І. Левіна, Л. Нічуговська, Г. Савченко, I. Теплицький,Л. Фрідман, В. Штофф та ін.) установлено, що моделювання пов'язане 3 теоретичним i практичним дослідженням об'єкта шляхом конструювання й вивчення моделі, яка імітує суттєві властивості оригіналу, здатна заміщувати його так, щоб їі використання надало нову інформацію про цей об'єкт.

Як з'ясовано під час дослідження, успішне виконання професійної діяльності значною мірою залежить від сформованості в майбутнього фахівця економічного профілю вмінь моделювання економічних об'єктів. Для визначення й класифікації цих умінь необхідно уточнити уявлення про поняття «вміння моделювання економічних об'єктів». На основі врахування різних поглядів науковців (О. Лаврентьєва, І. Лукаш, I. Левіна, В. Паламарчук, Г. Савченко та ін.) у контексті дослідження під умінням моделювання економічних об'єктів маємо на увазі складний комплекс розумових і практичних дій, який забезпечує отримання інформації про досліджуваний об'єкт на основі попереднього вивчення, визначення його найсуттєвіших характеристик, конструювання моделі, iї теоретичний та експериментальний аналіз, а також коригування створеної моделі на основі одержаної інформації.

Виходячи $з$ того, що вміння - це складна сукупність розумових і практичних дій, яка передбачає: 1) усвідомлення мети й умов діяльності; 2) формування завдань 
діяльності; 3) планування й вибір способів виконання дій; 4) контроль і самоконтроль за процесом діяльності [5], і проаналізувавши праці [1; 2; 3; 4; 6], ми дійшли висновку, що моделювання економічних процесів, явищ має такі етапи процесу моделювання: постановка завдання моделювання (визначення предмета й об'єкта дослідження економічних об'єктів); усвідомлення структурно-логічного взаємозв'язку між елементами об'єкта; визначення зв'язку між функціональною ознакою та чинниками; установлення взаємоузгодженості між чинниками, які впливають на результативність; аналіз наявності ресурсів моделювання (грошові засоби, час, програмне забезпечення, інформаційне забезпечення, наявність персоналу тощо); визначення методів дослідження (вибір методів для забезпечення виконання поставленогозавдання); перевірка можливості отримання всіх первинних даних для проведення дослідження обраним методом); розроблення моделі (визначення мети та завдань дослідження економічних процесів і систем); з'ясування джерел і періоду формування економічної інформації; визначення способу отримання економічної інформації; визначення форми подання економічної інформації; безпосереднє збирання економічної інформації; висування гіпотез і розроблення припущень; групування первинної економічної інформації у зведених табличних формах; проведення формальної та логічної перевірки даних; аналітичне опрацювання економічної інформації (оцінка повноти, достовірності, суттєвості, можливості порівняння, неперервності, адаптивності, оперативності, перспективності); пошук критеріїв, за якими оцінюватиметься достовірність моделі; подання результатів моделювання; оцінка надійності рівняння зв'язку; виявлення узгодженості одержаних знаків коефіцієнтів із загальноекономічним уявленням; інтерпретація одержаного рівня; 3'ясування початкових даних, обмежень і критеріїв досягнення мети, галузі використання та коло користувачів); реалізація ц̌ аналіз моделі (оцінювання розв'язку з різних позицій (конкретності, економічності, ефективності); визначення ефекту від реалізації моделі (можливість резервів за кожним чинником); визначення можливості застосування цієї моделі в подальших дослідженнях (прогнозуванні); визначення вірогідності застосування до інших економічних явищ; застосування моделі під час дослідження інших економічних процесів і систем; інтерпретація висновків; визначення на основі отриманих даних заходів, що сприятимуть виявленню та використанню резервів економії ресурсів; перевірка точності моделі та іiї адекватності реальному процесу); рефлексія, що є особливим етапом процесу моделювання, на основі якої відбувається коригування діяльності, критична оцінка здобутих знань і набутих умінь 3 огляду на поставлену мету й умови діяльності (визначення та оцінка досягнутих результатів; аналіз умов отримання результатів, ефективність методів, що застосовувалися; виявлення причин успіхів, невдач, помилок і труднощів; усвідомлення засвоєння методів моделювання економічних процесів і систем; корекція знань і умінь; пошук зв’язків між новими здобутими знаннями та попереднім досвідом).

Зазначені етапи вміння моделювати можна використовувати в різноманітних галузях економіки, при цьому змінюватиметься лише його операційний склад, тобто виконавча частина.

Відповідно до власного бачення сутності вмінь моделювання економічних об'єктів та їх ролі в професійній діяльності, виокремлення основних складників процесу моделювання (постановка завдання моделювання; розроблення моделі; реалізація й аналіз моделі, рефлексія) визначено групи вмінь моделювання економічних об'єктів:

- гностичні (уміння полягає в отриманні, аналізі й узагальненні інформації щодо 
об'єкта моделювання);

- проектувально-конструктивні (уміння передбачає визначення цілей моделювання,можливості їх досягнення в конкретних умовах і комплексу відповідних завдань (або планування процесу моделювання відповідно до цілей), забезпечує оптимальний вибір форм і способів подання досліджуваного об'єкта);

- дослідницько-творчі (уміння полягає в застосовуванні прийому моделювання в умовах розв'язання навчальної проблеми, у процесі виконання навчальнодослідницького завдання);

- оцінно-рефлексивний (уміння передбачає здійснення оцінної діяльності, спрямованої на себе, на осмислення й аналіз власних дій).

Викладене вище дозволило дійти висновку, що кожному із зазначених складників процесу моделювання відповідає певна група вмінь, яка забезпечує процес моделювання економічних об'єктів (табл. 1).

Класифікація вмінь моделювання економічних об'сктів

Таблиия 1

\begin{tabular}{|c|c|c|}
\hline $\begin{array}{c}\text { Групи вмінь } \\
\text { моделювання }\end{array}$ & $\begin{array}{c}\text { Складники процесу } \\
\text { моделювання }\end{array}$ & Перелік умінь \\
\hline 1 & 2 & 3 \\
\hline Гностичні & $\begin{array}{l}\text { Постановка завдання } \\
\text { моделювання }\end{array}$ & 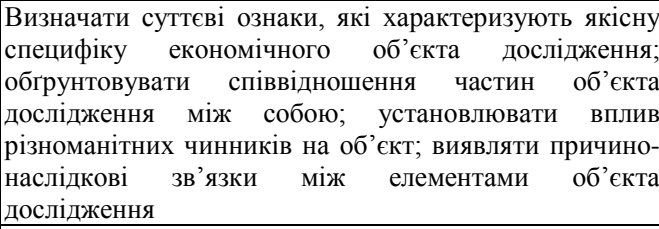 \\
\hline $\begin{array}{l}\text { Конструктивно- } \\
\text { проектувальні }\end{array}$ & Розробленнямоделі & $\begin{array}{l}\text { Визначати мету та завдання моделювання, форму, } \\
\text { спосіб подання економічної інформації; складати } \\
\text { алгоритм моделювання; синтезувати отриману } \\
\text { інформацію у вербальні конструкції, текстові й } \\
\text { графічні моделі; обгрунтовувати критерії оцінювання } \\
\text { достовірності моделі, галузь її використання та коло } \\
\text { користувачів }\end{array}$ \\
\hline $\begin{array}{l}\text { Дослідницько- } \\
\text { творчі }\end{array}$ & $\begin{array}{l}\text { Реалізація й аналіз } \\
\text { моделі }\end{array}$ & $\begin{array}{l}\text { Аналізувати отриманий розв’язок моделювання; } \\
\text { порівнювати різні варіанти моделей та обират } \\
\text { найприйнятнішу; переносити отриманий результат на } \\
\text { економічний об'єкт; виявляти загальні властивості } \\
\text { досліджуваного об'єкта; визначати межі застосуванн } \\
\text { моделі }\end{array}$ \\
\hline $\begin{array}{l}\text { Оцінно- } \\
\text { рефлексивні }\end{array}$ & Рефлексія & $\begin{array}{l}\text { Визначати умови правильності отриманих результатів; } \\
\text { виявляти причини успіхів, невдач, помилок; } \\
\text { здійснювати контроль і самоконтроль; доповнювати } \\
\text { чи змінювати план, програму, форми й методи } \\
\text { моделювання; оцінювати підсумки власної діяльності }\end{array}$ \\
\hline
\end{tabular}

Аналіз навчального плану та навчальних програм за галуззю знань 0305 «Економіка та підприємництво» дозволив констатувати, що формуванню знань i виробленню вмінь моделювання економічних об'єктів сприяють дисципліни як професійного, так i природничо-наукового та соціально-гуманітарного циклів (табл. 2).

Не менш важливу роль у процесі формування й розвитку вмінь моделювати відіграють навчальна, виробнича практики, виконання курсових і дипломних робіт. У період навчальної практики студенти набувають умінь моделювати окремі 
управлінські задачі з обліку та фінансів, інформаційного моделювання. Проходження виробничої практики надає змогу застосовувати вміння комплексного моделювання під час виконання конкретних виробничих ситуацій в обліковій і фінансовій діяльності суб'єктів господарювання.

Табличя 2

Знання, необхідні для набуття вмінь моделювання економічних об'єктів

\begin{tabular}{|c|c|c|}
\hline Знання & Назва навчальної дисципліни & Курс \\
\hline 1 & 2 & 3 \\
\hline $\begin{array}{l}\text { Основні дефініції моделювання, } \\
\text { етапи становлення та розвитку } \\
\text { поняття «модель», «моделювання» }\end{array}$ & $\begin{array}{l}\text { «Філософія», } \\
\text { «Основи наукових досліджень», } \\
\text { «Вступ до фаху “Фінанси і кредит”» }\end{array}$ & 1 \\
\hline $\begin{array}{l}\text { Моделі, які мали ключове значення } \\
\text { в історії економіки }\end{array}$ & $\begin{array}{l}\text { «Політична економія», «Макроекономіка», } \\
\text { «Мікроекономіка», «Історія економіки та економічної } \\
\text { думки» }\end{array}$ & 1,2 \\
\hline $\begin{array}{l}\text { Роль i місце моделювання, } \\
\text { класифікація та сфера застосування } \\
\text { моделей під час } \\
\text { соціально-економічних } \\
\text { вировення } \\
\text { явичих процесів }\end{array}$ & $\begin{array}{l}\text { матика для економістів», } \\
\text { ична економія», } \\
\text { еекономіка» }\end{array}$ & 1,2 \\
\hline $\begin{array}{lcr}\text { Інформаційна } & \text { база } & \text { процесу } \\
\text { моделювання, способи } & \text { подання } \\
\text { iнформації в табличній і графічній } \\
\text { формах }\end{array}$ & $\begin{array}{l}\text { катика», } \\
\text { тика», «Економічний аналіз», «Управлінський }\end{array}$ & $\begin{array}{ll}1,2 \\
3\end{array}$ \\
\hline $\begin{array}{l}\text { Моделювання } \\
\text { ситуацій в умовах використання } \\
\text { iнформаційних технологій }\end{array}$ & $\begin{array}{l}\text { «Математичне програмування», } \\
\text { системи й технології у фінансах» }\end{array}$ & 3,4 \\
\hline $\begin{array}{l}\text { Сутність } \\
\text { моделювання в економіці, зміст } \\
\text { процесу моделювання та його } \\
\text { основні етапи, форми вираження } \\
\text { моделей }\end{array}$ & $\begin{array}{l}\text { «Статистика», «Економіка } \\
\text { «Економетрія», } \\
\text { «Економічний аналіз», } \\
\text { «Оптимізаційні методи та моделі» }\end{array}$ & 2,3 \\
\hline $\begin{array}{l}\text { Методика й техніка моделювання } \\
\text { під час вивчення соціально- } \\
\text { економічних явищ і виробничих } \\
\text { процесів, прийняття управлінських } \\
\text { рішень }\end{array}$ & $\begin{array}{l}\text { «Економічний аналіз», «Аудит», «Статистика } \\
\text { підприємств», «Фінанси підприємств», «Фінансовий } \\
\text { менеджмент», «Економіко-математичні методи й } \\
\text { моделі у фінансових розрахунках», «Моделі й методи } \\
\text { прийняття рішень в аналізі та аудиті» }\end{array}$ & \\
\hline
\end{tabular}

Завершальним етапом у процесі підготовки фахівців щодо формування вмінь моделювання $\epsilon$ дипломна робота, метою якої $\epsilon$ застосування методів наукового дослідження для розв'язання практичних завдань, систематизація, закріплення, розширення теоретичних і практичних знань зі спеціальності та використання методу моделювання у процесі розв'язання актуальних проблем в економічній галузі, опанування методу моделювання, застосування його на практиці. Під час написання дипломних робіт студенти набувають уміння виявляти суперечності, визначати мету моделювання, обирати форму подання моделі, аналізувати отриману модель на адекватність об'єкту та меті моделювання, переносити результат, отриманий за допомогою моделювання, на реальний об'єкт, проводити експеримент із реальним об'єктом, формулювати висновки.

Вагомий вплив на формування вмінь моделювання у студентів вищих економічних навчальних закладів має система завдань, спрямована на формування зазначених умінь: завдання на розуміння (виявити фактори, що діють у сфері стягнення того чи іншого податку); завдання на репродуктивну діяльність (за 
аналогом розрахувати точки критичного обсягу продажу товарів); завдання на продуктивну діяльність (здійснити узагальнення, упорядкування інформації про наявність і рух усіх типів основних засобів на підприємстві; у табличній формі подати одержані дані, визначити вплив різноманітних факторів на структуру виробничих запасів); завдання на творчу діяльність (проаналізувати динаміку індексу цін і рівня інфляції на визначення вартості власного «споживчого кошика»).

Навчальні завдання, спрямовані на формування вмінь моделювання у студентів вищих економічних навчальних закладів, класифіковано відповідно до функцій моделей: описові (проаналізувати поняття «моделювання»; зіставити узагальнену структуру діяльності моделювання; порівняти різні підходи до класифікації моделей, оцінити їх з логічної точки зору; указати, чим відрізняються ці моделі; здійснити порівняльний аналіз запропонованихмоделей); конструктивні (розробити структуру процесу моделювання конкретних видів моделей, план програми моделювання конкретних видів моделей; запропонувати різні способи діяльності у процесі моделювання конкретних видів моделей, програму діяльності; створити модель конкретного виду, сконструювати зміст моделей різних видів); евристичні (виявити й охарактеризувати конкретні класифікації моделей; запропонувати й обгрунтувати послідовність операцій діяльності моделювання; підготувати і провести презентацію моделі конкретного виду; знайти узагальнену модель для класу процесів або явищ, набір моделей для одного процесу; проаналізувати економічні процеси або явища на основі розроблених моделей; порівняти інваріанти моделей (оцінити недоліки й переваги наявних моделей) та обрати оптимальний).

Окресливши структуру, знання, необхідні для набуття вмінь моделювання економічних об'єктів, важливо визначити їх рівні розвитку. Спираючись на дослідження [7], було розроблено критерії i показники вмінь моделювання в єдності компонентів: мотиваційного (сформованість мотивів до навчальної діяльності), когнітивного (рівень засвоєння студентами знань, необхідних для здійснення моделювання), процесуального (сформованість визначених груп умінь моделювання; самостійність застосування моделювання); виокремлено такі рівні: високий, середній, низький.

На основі аналізу філософської й психолого-педагогічної літератури розкрито сутність поняття«уміння моделювання економічних об'єктів» складний комплекс розумових і практичних дій, що забезпечує отримання інформації про досліджуваний об'єкт на основі попереднього вивчення, визначення його найсуттєвіших характеристик, конструювання моделі, іiі теоретичний та експериментальний аналіз, а також коригування створеної моделі на основі одержаної інформації.

Здійснено класифікацію вмінь моделювання економічних об'єктів (гностичні, проектувально-конструктивні, дослідницько-творчі, оцінно-рефлексивні) відповідно до складників процесу моделювання (постановка завдання моделювання; розроблення моделі; реалізація й аналіз моделі; рефлексія).

Уточнено критерії, показники рівнів сформованості вмінь моделювання в єдності компонентів: мотиваційного, когнітивного; процесуального.

Проведене дослідження не вичерпує всіх аспектів проблеми. Зазначені компоненти формування вмінь моделювання потребують більш детального розгляду в подальших наукових дослідженнях.

\section{Література}

1. Батороев К. Б. Аналогии и модели в познании / К. Б. Батороев. Новосибирск : Наука, 1981. - 319 с. 2. Гальперин П. Я. Психология мышления и учение о поэтапном формировании умственных действий / П. Я. Гальперин // 
Хрестоматия по психологии :[учеб. пособие для студ. пед. ин-тов] / [под ред. проф. А. В. Петровского]. - М. : Просвещение, 1997. - С. 400-424. 3. Лов'янова I. В. Формування інтелектуальних умінь старшокласників у процесі вивчення предметів природничого циклу: автореф. дис. на здобуття наук. ступеня канд. пед. наук: спец. 13.00.09 «Теорія навчання» / I. В. Лов'янова. - К., 2006. - 20 с. 4. Монастирна Г. В. Формування професійної компетентності майбутніх учителів інформатики засобами інформаційно-педагогічного моделювання: автореф. дис. на здобуття наук. ступеня канд. пед. наук: 13.00.04 «Теорія і методика професійної освіти» / Г. В. Монастирна; Луганський нац. ун-т ім. Тараса Шевченка. - Луганськ, 2009. - 20 с. 5. Нічуговська Л. І. Науково-методичні основи математичної освіти студентів економічних спеціальностей вищих навчальних закладів: автореф. дис. на здобуття наук. ступеня д-ра пед. наук: спец. 13.00.04 «Теорія і методика професійної освіти» / Л. І. Нічуговська. - К., 2005. - 36 с. 6. Новик И. Б. О моделировании сложных систем / И. Б. Новик. - М. : Мысль, 1965. - 335 с. 7. Савченко Г. О. Формування готовності майбутніх фахівців банківської справи до аналітичної діяльності засобами моделювання: автореф. дис. на здобуття наук. ступеня канд. пед. наук: спец. 13.00.04 «Теорія і методика професійної освіти» / Г. О. Савченко. - Одеса, 1993. - 18 с.

УДК 377.35

Людмила Цвіркун

\section{ПРОЕКТНО-КОНСТРУКТОРСБКА КОМПЕТЕНТНІСТЬ ЯК СКЛАДНИК ПРОФЕСІЙНОЇ ГОТОВНОСТІ МАЙБУТНЬОГО ІНЖЕНЕРА}

Цвіркун Л. О. Проектно-конструкторська компетентність як складник професійної готовності майбутнього інженера.

У статті розглянуто наукові поняття «професійна компетенція», «професійна компетентність» та «проектно-конструкторська компетентність майбутнього інженера», уточнено сутність використовуваних понять в аспекті компетентнісного підходу, конкретизовано терміни та надано авторське визначення проектноконструкторської компетентності як невід'ємного складника професійної готовності майбутнього інженера.

Ключові слова:інженер, компетентнісний підхід, професійна компетенція, професійна компетентність, проектно-конструкторська компетентність майбутнього інженера, графічні дисципліни.

Цвиркун Л. А. Проектно-конструкторская компетентность как составляющая профессиональной готовности будущего инженера.

В статье рассмотрены научные понятия «профессиональная компетенция», «профессиональная компетентность» и «проектно-конструкторская компетентность будущего инженера», уточнена сущность использованных понятий в аспекте компетентностного подхода, конкретизированы термины, дается авторское определение проектно-конструкторской компетентности как неотъемлемой составляющей профессиональной готовности будущего инженера.

Ключевые слова: инженер, компетентностный подход, профессиональная компетенция, профессиональная компетентность, проектно-конструкторская компетентность будущего инженера, графические дисциплины.

Tsvirkun L. O. Design and engineering expertise are the training of future engineers.

The article describes the scientific concept of «expertise», "professional competence» and «design and engineering expertise of the future engineer» refine the concepts used in the aspect of the competency approach concretized terms and given the author's definition of 